\title{
Analysis of Lending by Public and Private Micro-Financial Institutions to Microenterprises in Nuwara Eliya
}

\author{
H.M.A.Chulangani and A. Ariyawardana \\ Dept. of Agricultural Economics, Faculty of Agriculture, University of Peradeniya, \\ Peradeniya
}

\begin{abstract}
Microenterprise activities could be considered as one of the best solutions for poor people to realize their potentials and to improve their economic status. However, access to credit is a critical issue that influences the development of microenterprises. The Credit Delivery System (CDS) varies among different lenders and there are differences in terms and conditions of the loans as well as in lender's and borrower's transactions costs. Therefore, this study was conducted to analyze the lending by public and private micro-financial institutions to micro-enterprises in the Nuwara Eliya Divisional Secretariat. Based on the level of involvement, the Samurdhi Development Bank and Ceylinco Grameen Credit Company Limited were selected to represent the public and private sector.
\end{abstract}

Ninety microenterprise owners who have borrowed from these two sources were selected randomly. Primary data were collected through a pre-tested questionnaire. Analysis revealed that the Ceylinco Grameen Credit Company Limited has a low transaction cost than the Samurdhi Bank; however it charges a higher interest rate and this leads to a higher gross unit cost of borrowing. Findings suggest that the transaction cost of borrowing declines as the size of loan increases. Transaction cost of borrowing increases due to high travel cost and opportunity cost of borrowing. Closer proximity to the borrower, regular inspection of microenterprises by the lending staff, timeliness in loan approval and disbursement have built a strong relationship with the Ceylinco Grameen Credit Company Limited. Incorporation of these factors into the Samurdhi Bank CDS could reduce the borrower's transactions cost.

Key words: Micro-Financial Institutions, Credit Delivery System, Transactions Costs, Microenterprises

\section{Introduction}

Poverty is a major economic problem in Sri Lanka and hence various poverty alleviation programmes have been implemented by successive governments in the past. However, eradication of poverty is not possible either by providing food subsidy or by creating job opportunities. According to Yunus (1999), the poor can be saved by providing them an opportunity to realize their potentials. He has pointed out that poor are poor not because they are lazy, untrained or illiterate but because they cannot earn genuine returns on their labour. Therefore, creating opportunities and empowerment of the poor could be considered as the way to end poverty (Bhatt, 1998; Yunus, 1999).

According to Yunus (1999), self-employment which leads to microenterprise activities may be the only solution for poor people to realise their potentials and it will not only increase their economic security but also their social status. Therefore, any assistance given to microenterprises to overcome challenges faced by them would lead to create more successful enterprises (Seneviratne, 1999). Access to capital is a critical issue for microenterprises. Credit is an alternative way to acquire capital and it helps to overcome financial constraints faced by microenterprises. However, these small firms typically cannot access the traditional capital market like larger publicly held firms (Premaratne, 2002). 
In many government sponsored credit programmes the interest rates are held low. However, the other terms and conditions like filling forms, requirement of guarantors and collateral increases the transaction costs and make borrowers' cost of funds roughly equal to the cost of alternative funds that they could obtain elsewhere. Given this problem, many new credit schemes seek to reduce the transaction cost of the small borrowers. However, research on determining the borrower's transaction costs with respect to different lending sources to microenterprises are limited. Therefore, this study was conducted to analyze the lending by public and private micro-financial institutions to microenterprises in Nuwara Eliya Divisional Secretariat. Specifically, this study aims to determine and compare the borrower's transactions cost and to analyse the perception of microenterprise owners towards the lending institution.

\section{Microenterprises}

A microenterprise cannot be defined using a single, clear and widely accepted definition. Most of the microenterprises are found in the informal sector, and are often itinerant businesses; most remain small in size, yet are critical to the family's economic livelihood. Different institutions adapt their own definitions which suit their purposes such as discussion of policy applications, taxation and other legislations.

- The Department of Census and Statistics of Sri Lanka defines microenterprises as those non-agricultural household-based enterprises employing less than five persons. The term could refer to a range of economic activities from self-employment to those which employ one or two hired workers in addition to the family.

- The Department of Industrial Development and Enterprise Promotion in Sri Lanka (2006) classifies the microenterprises according to two basic characteristics. Enterprises where the number of employees is less than 5 and total investment (except land and building) is less than one million rupees are categorized as a microenterprise.

- Gunathilaka (1997) defines microenterprises as those agricultural or industrial economic activities not employing more than five persons.

- Seneviratne (1999) describes microenterprises as the sector which has passed the self-employment and cottage industries/ventures level but not developed up to the small and medium scale level.

Microenterprise is the developed stage of self-employment activities. Smith (1999) defined the self-employees as survivalists (or pre-entrepreneurs) owning family-based businesses with a survival character, in which part time, often seasonal activities are undertaken. Their main objective is to generate family income. A large part of the increase in employment in the 1980s is due to selfemployment and unpaid family work (i.e. informal sector). The share of self employment in the microenterprise sector remained high at around $25 \%$ throughout the 1980s (Kelegama and Thiruchelvam, 2001) and at around 28\% during last five years (Central Bank of Sri Lanka, 2004).

Seneviratne (1999) has created a model to show the development of the selfemployment activities up to macro level enterprises. According to Figure 1, a business initiated as a self-employment activity can be developed into a microenterprise by overcoming the constraints that they face. Further 
development of the microenterprises will end up at the macro level as large scale businesses.

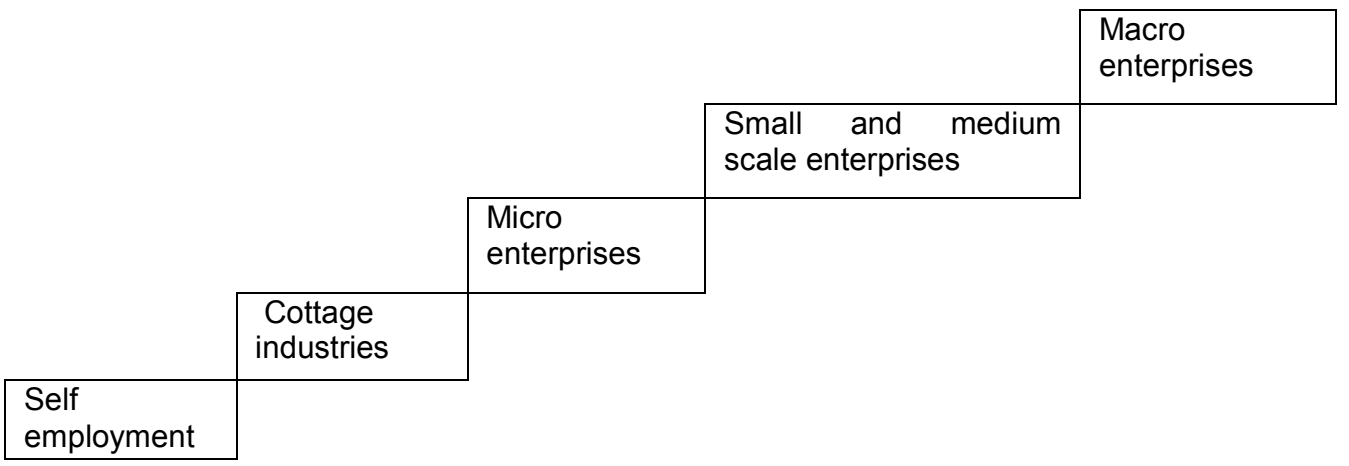

Figure 1: Development of Microenterprises in Sri Lanka.

Source: Seneviratne, 1999

\section{Importance of Micro-Credit for Microenterprises}

Microenterprises should be supported with necessary requirements in order to develop into macro level businesses. In this context, access to credit is a critical issue for microenterprise owners. Micro-credit is a means of providing finance in small quantities, at a reasonable cost and with conditions that are both convenient and suitable for the enterprises undertaken by the microenterpreneurs (Sanderatne, 2002). As Premaratne (2002) reveals, micro and small lending tools help to increase the flexibility, efficiency, and effectiveness of capital and other resources in developing countries like Sri Lanka. Informal, formal and the micro-financial sources are the lending sources available for the microenterpreneurs in Sri Lanka.

Basically, micro-credit is a part of microfinance, where microfinance is credit and savings that enable people to begin or expand microenterprises or other income generating activities and accumulate their small savings safely (Sandaratne, 2002). According to Chandradasa (2004), the term "microfinance" refers to small scale financial services - primarily credit and savings - provided to economically active, low income clients. Micro-credit helps to improve the lives of millions of people in the world even though these efforts are not shown in statistics.

As revealed by Delpachitra (2000) microfinance institutions have initiated lending programmes to microenterprise owners using a new set of technologies that have been appropriated to the local and regional environment. Some of these programmes include Samurdhi Development Fund in Sri Lanka, Grameen Bank in Bangladesh, Unit Desa System of Bank Rakyat Indonesia (BRI) and Vietnam Bank for the poor. The achievements of these micro-credit institutions in the 
Asian region have remarkably been positive along with the success story of the Grameen Bank of Bangladesh.

\section{Transactions Cost}

Several authors have explored the role of transactions cost in CDS. According to Ladman (1988), the transactions costs consist of non interest expenses incurred by both lenders and borrowers in making (obtaining), servicing (implementing), and collecting (repaying) loans. The transactions cost can be viewed in two directions. One is from the lender's view and the other is from the borrower's view.

\section{Lender's Transactions Cost}

The steps followed by lenders in delivering credit to their borrowers, formulate the lender's transactions cost. The CDS and associated transactions cost vary depending upon the strength of their reasons for collecting information, their means of collecting it and their services. Lenders incur transactions cost when they have employees to supervise credit. Many lender procedures are aimed at gathering information about a prospective borrower. This is done mainly to protect the lender's funds by determining the prospective borrower's creditworthiness and to provide internal control on funds lent.

As revealed by Ladman (1988), the institutions that engage in micro lending should have a good understanding about the microenterprise owners and their credit requirements. The most direct way to reduce the transactions cost is to simplify the CDS. According to Otero and Rhyne (1994), another means of decreasing the transactions cost is to reduce procedures, documentation and to focus on repeat borrowers about whom lender has already accumulated considerable information. Lender transactions cost is assumed to be more or less constant, irrespective of the loan size.

\section{Borrower's Transactions Cost}

To obtain a loan, borrower not only must consider the agreed-upon conditions of the loan but also must go through the procedures that are required by the lender's CDS. As defined by Ladman (1988), the costs associated with the steps the borrower undertakes to complete the lender's requirements result in borrower transaction cost. This is the most important determinant in accessing credit by the microenterprise owners. When the procedures become complex, the CDS also become complex to the borrower. Under these conditions borrower may have to spend a high cost to complete the steps of the loan procedure. The costs associated in fulfilling these steps result in borrower transaction costs. According to Ladman (1988) and Sanderatne (2002) the borrower's transaction cost include,

- The out-of-pocket outlays required to obtain documents

- Commissions and bribes

- Travel to and from the lender's office

- The opportunity costs of time involved to complete all required procedures 
If there are delays in loan approvals or disbursements, the borrower may incur additional transactions costs in obtaining a temporary loan from another lender (Ladman, 1988). According to Morapitiya (1998), actors of the informal markets have generally been successful in keeping the lender's and borrower's transaction costs to a very low level and loan collection at a very high level. However, this is considered to be the other way round in the formal financial markets and hence it is critically important to find ways to decisively reduce the transaction costs and defaults through increased risk management.

Adams and Newman (1979) examined how borrowing behaviour is affected by total borrowing costs, including transactions costs and interest payments. They presented evidence from several countries showing how borrower transactions costs lead to high borrowing costs from many formal lenders. They conclude that relatively large transactions costs discourage the rural poor from borrowing from these sources.

The research done by Ladman (1988) reveals that a lender will attract more clients when borrower transactions costs for loans are lowered. He further reveals that the elimination of concessionary interest rates is the key to lowering transactions costs and allowing banks to serve a large number of small borrowers.

According to Ladman (1988) the borrower transaction costs have at least three impacts on profitability; first, larger the borrower transactions cost the lesser the profits for the borrower. Second, there is a minimum loan size below which the borrower would not be willing to borrow from a lender. Third, the out-of-pocket costs represent the amount of outlay the borrower must make in applying for a loan.

Orlando (1994) found that the borrower's transactions costs significantly increase the total cost of borrowing particularly for small loans. He further concluded that the transactions cost of the financial institution as well as that of the borrowers greatly varies according to the nature of the institution. According to Sanderatne (2002), borrowers transaction cost appeared as zero with the informal sources and high with the institutional sources.

\section{Reasons for High Transactions Cost}

The variations in the credit delivery systems cause a high transaction cost for the borrower. The major service needs for the poor microenterprise owners are saving and credit for liquidity and working capital, with easy repayment terms of one year or less. Credit should not be directed to specific uses (Otero and Rhyne, 1994: Sanderatne, 2002). Therefore, the institutions that engage in micro lending have to have a good understanding about the microenterprise owners and their credit requirements. A lending outlet located near the client, simple application procedure and small loans quickly disbursed are all important. For access and convenience, microenterprise owners are willing to pay higher interest rates than formal lending rates (Otero and Rhyne, 1994: Sanderatne, 2002). Therefore, the credit delivery system of any institution should be based on the requirements demanded by the microenterprise owners.

Complexity in the CDS results in high transactions cost on borrowings. The lending institutions having quick, simple and decentralized loan procedures will attract microenterprise owners towards the lending source (Otero and Rhyne, 1994: Sanderatne, 2002). However, the loan processing burden could be 
reduced by allowing borrowers to form groups (Otero and Rhyne, 1994: Yunus, 2000).

The barrier for the microenterprise owner in obtaining loans is the collateral. Therefore, it is considered that the traditional collateral requirement should be replaced (Otero and Rhyne, 1994: Premaratne, 2002: Sanderatne, 2002) with well developed techniques to ensure high repayment rates supported by peer pressure and required savings programmes (Otero and Rhyne, 1994: Yunus, 2000).

\section{The "Gross Unit Cost" of a Loan}

Cost of credit is composed of two components, namely, the interest cost and transactions cost. If all transaction costs are measured quantitatively and added to the interest, the resulting cost can be considered as the "gross unit cost of loan". From the economic point of view, the "gross unit cost" is the cost per unit of money borrowed. The most important character of unit transaction cost which is the transaction cost per rupee of loan obtained is that it declines as the size of the loan increases (Egaitsu, 1988).

\section{Methodology}

Nuwara Eliya Divisional Secretariat was selected purposively for this study. Nuwara Eliya is a semi urbanized area where farming is the major income generating activity of the people. Other than farming, most of these people are engaged in different self-employment and microenterprise activities which are inherent for the area. Among them, selling vegetables, fruits and flowers, rearing milking cows and small scale strawberry cultivation are leading activities.

Different lending sources are available for the microenterprise owners in Nuwara Eliya. However, only two dominant lending sources to micronterprises were selected for the study to represent the public and private sector. The Samurdhi Development Bank which is the most dominant government sector institution focusing on poor and the Ceylinco Grameen Credit Company Limited which is the leading private sector institution focusing on poor were the two lending sources selected for the study.

Sampling is crucial for data analysis. The decision on whom to look at or talk with, where, when, about what and why are important in determining sampling (Miles and Hberman, 1994). Microenterprise owners who have obtained credit from the Samurdhi Development Bank and the Ceylinco Grameen Credit Company Limited to commence or develop microenterprise ventures, were considered as the sampling frame. There are five Samurdhi Development Banks functioning in Nuwara Eliya Divisional Secretariat. Each bank had a loan portfolio of Rs. 45 million by the middle of 2006. Among those, Nuwara Eliya, Kandapola and Bangalahatha Banks were selected randomly. Fifteen borrowers were selected randomly from each bank to make a total of 45 borrowers from the Samurdhi Development Bank.

There is a Nuwara Eliya Branch Office of the Ceylinco Grameen, functioning within the Nuwara Eliya Divisional Secretariat. By the middle of 2006, the Nuwara Eliya branch has disbursed Rs. 105 million worth loans to their clients. Under the Ceylinco Grameen Nuwara Eliya Branch, 63 centers are functioning, where each 
consists of 75 members. Forty five borrowers were selected randomly from 30 centers. Primary data were gathered through a questionnaire which consisted of two variables, namely, information related to transaction cost of borrowing and information on the perception towards the lending source. The information about the transaction cost of borrowing was collected under the following categories.

- Geographical distance from the household to the lending institute. Two components are included under this category.

- $\quad$ Borrower's traveling and meal expenses (Rupees)

- $\quad$ Opportunity cost of the time lost (Hours)

- Complex procedures of the lending institute. The following cost components are included under this category.

- $\quad$ Cost involved in filling the loan application (Rupees)

- $\quad$ Cost of finding Guarantors (Rupees)

- $\quad$ Cost of bribes given to obtain the loan (Rupees)

- $\quad$ Any other cost involved (Rupees)

The time cost of one day has been evaluated as equivalent to income of one day from the microenterprise and calculated according to the time spent by each borrower in the process of acquisition and repayment of the loan. The borrower's perception towards the lending source was estimated using fourteen statements related to the lending procedure, the lending source, loan and loan usage.

The questionnaire was pre-tested and required adjustments were done before the data collection. Differences between the two lending sources were explored by using $t$-test and the transactions costs were calculated as follows.

\section{Calculation of the Average Transactions Cost per Rs.100 Loan}

The total transaction cost was calculated by adding the costs incurred in obtaining the loan. The travel and meal cost, opportunity cost of borrowing, cost of finding guarantors and any other cost involved in obtaining the loan were included in the transactions cost calculation. There were no cost in obtaining and filling loan application and hence ignored in the calculation process. Cost of bribes was not considered in the transactions cost calculation as all the respondents were not able to provide accurate figures. First, the transactions cost per Rs. 100 of loan was calculated for each individual and averaged to obtain the average transaction cost per Rs. 100 of loan.

\section{Calculation of the Percentage Cost Contribution of each Cost Component to the Average Transactions Cost per Rs. 100 Loan}

Contribution of each cost component to the transaction cost of obtaining Rs. 100 loan for each individual was calculated first and then the average was calculated. The cost of obtaining and filling loan application and cost of bribes given were not considered in calculating the percentage contribution to the transaction cost.

\section{Calculation of the "Gross Unit Cost" of Loan}

If all transaction costs are measured quantitatively and added to the interest, the resulting cost can be considered as the "gross unit cost of credit". The following equation was used to calculate the gross unit cost of loan. 


$$
\begin{array}{ll}
G=Q+T & g=\frac{Q}{B}+\frac{T}{B} \\
I=Q / B & t=T / B
\end{array}
$$

Where,

$\mathrm{G}=$ Gross cost, $\mathrm{g}=$ Gross unit cost, $\mathrm{B}=$ Loan size, $\mathrm{t}=$ Unit transaction Costs,

$\mathrm{I}=$ Rate of Interest, $\mathrm{Q}=$ Interest Cost, $\mathrm{T}=$ Transactions cost

Borrower's perception towards different lending sources was analyzed by using a 1 to 5 likert scale. There were 14 statements in this category. Therefore, one respondent can score between 14-70. Any score between 14-42 was considered as a negative perception and a score between 43-70 was considered as a positive perception towards the lending source.

\section{Results and Discussion}

Microenterprises were categorized into 7 categories based on their involvement. They are the crop-based, animal-based, food processing, textile and garments, service supply, trade related and other types. Thirty one per cent of Ceylinco Grameen and $40 \%$ of Samurdhi Bank borrowers are engaged in trade related microenterprise activities. Most dominant trade related activities are selling vegetables, fruits, flowers and flower plants at the roadside and small scale retail shops. The Samurdhi Bank has provided small, wooden made, mobile rooms called "Samurdhi Kuti" to their borrowers. Therefore, most of the Samurdhi Bank borrowers are engaged in trade related microenterprises.

Thirteen per cent of Samurdhi Bank borrowers and $24 \%$ of Ceylinco Grameen borrowers are engaged in crop-based activities. Those microenterprises are the strawberry, mushroom and coriander leaves cultivation. Fifteen and $18 \%$ borrowers from the Ceylinco Grameen and Samurdhi Bank respectively are engaged in animal-based microenterprises. They rear milking cows and sell milk to Nestle and Milco milk collecting centres.

Thirteen percent of Ceylinco Grameen borrowers and 9\% of Samurdhi Bank borrowers are engaged in food processing activities. Only females are engaged in food processing activities such as making lunch packets, string hoppers and short-eats. They sell their products to hotels, restaurants or directly to customers. Nine per cent of Ceylinco Grameen borrowers and $18 \%$ of Samurdhi Bank borrowers are involved in selling textile and garments. Some of them bring garments from Colombo and sell to the village customers and women are engaged in tailoring businesses. A smaller percentage of service supplying microenterprises were observed. Providing transport facilities at village level is the major service supplying business. Four percent of Ceylinco Grameen and 6\% of Samurdhi Bank borrowers are involved in other businesses. Small carpentry shops and making Rattan baskets for tea pluckers are among them.

\section{Gender Distribution of the Microenterprise Owner}

The Ceylinco Grameen Credit Company Limited provides loans only to females. Although the borrower is always a female, there are only $29 \%$ female owned businesses among Ceylinco Grameen borrowers. The other female borrowers have invested the borrowed money in their family businesses owned by either 
their son or husband. In contrast, the Samurdhi Bank provides loans to both female and male-owned businesses. Among them there were $42 \%$ male-owned and $58 \%$ female-owned businesses. Even though the aim of the Ceylinco Grameen is to uplift poor rural women, by lending only to females, percentage of female-owned businesses who have borrowed from the Samurdhi Bank is greater than the Ceylinco Grameen. Majority of the females who have borrowed from the Samurdhi Development Bank have invested on businesses operated by them.

\section{Income from the Microenterprise}

Income is the most important factor that determines the sustainability of the microenterprise. Table 1 shows that $33 \%$ of the Samurdhi Bank borrowers are earning an income between Rs. $3001-4000$ per month. But 58\% of the Ceylinco Grameen borrowers are earning an income higher than Rs. 6000 per month. Analysis revealed that the average income level of a Samurdhi Bank borrower is significantly different from the average income level of a Ceylinco Grameen borrower. This could be due to the limited trade related activities by the Samurdhi Bank borrowers because they mainly do their activities in "Samurdhi Kuti" which has a limited store space.

Table 1: Income Gained from the Microenterprise

\begin{tabular}{|c|c|c|}
\hline $\begin{array}{c}\text { Income Category } \\
\text { (Rupees per } \\
\text { month) }\end{array}$ & $\begin{array}{c}|c| \\
\text { Ceylinco of Households } \\
(\boldsymbol{n = 4 5 )}\end{array}$ & Samurdhi Bank (n=45) \\
\cline { 2 - 3 } & - & 11 \\
$2001-3000$ & 11 & 22 \\
$3001-4000$ & 13 & 33 \\
$4001-5000$ & 11 & 25 \\
$5001-6000$ & 58 & 9 \\
$>6000$ & Rs. 3822.22 & - \\
\hline Average income & & Rs. 7944.44 \\
& & \\
\hline
\end{tabular}

\section{Information about the Loans}

The Ceylinco Grameen borrowers are females and they are required to join the institute in self-formed groups of five. The officers from the bank come to the people in the village. Loan repayments are made in weekly meetings consisting of fifteen groups held in the villages where members live. Five percent of the loan is kept as savings in individual accounts. The Samurdhi Bank lends to both males and females. They have to form five member groups and have to start a group saving account in order to become eligible to obtain loans from the bank. Non Samurdhi beneficiaries also can apply for loans by having a five member group. Borrowers have to visit the bank for loan repayments. Unlike the in the Samurdhi bank, borrowers of the Ceylinco Grameen have to follow a well defined procedure set by the lending institute. Borrower should start with a loan of Rs. 5,000; after repaying it borrower would be eligible for Rs. 10,000 loan. Similarly borrower can proceed gradually up to higher loans. Any loan should be repaid in 52 installments. But borrowers may possibly repay as soon as they can and apply for another loan. 
Majority of the Ceylinco Grameen borrowers (36\%) and Samurdhi Bank borrowers (67\%) are in the loan category of Rs. $20001-30000$. Although $22 \%$ of the Ceylinco Grameen borrowers have obtained loans above Rs. 50001 , Samurdhi Bank borrowers have not obtained such loans as the Samurdhi Bank does not lend higher loans to their borrowers.

Information about the Borrower's Transaction Cost

Six cost components, namely, travel and meal cost, opportunity cost of borrowing, cost of buying and filling loan applications, cost of finding guarantors, cost incurred as bribes and other costs related to loan were included in the transaction cost. There were no costs related to obtaining and filling loan applications, because in the Ceylinco Grameen Credit Company Limited, the staff completes all the related documents on behalf of their clients. In Samurdhi Bank lending, the Samurdhi Animators or group members help in filling the loan application on behalf of the illiterate borrowers. The cost incurred for bribes was ignored in calculating the transaction cost, since only $20 \%$ of Samurdhi Bank borrowers were able to give actual information related to bribes.

The borrower's transaction cost was calculated by using the travel and meal cost, opportunity cost of borrowing, cost of finding guarantors and any other cost incurred in obtaining the loan. The calculation processes of these are explained in the methodology.

\section{Transaction Cost per 100 rupees of loan}

First, the borrower's transactions cost per 100 rupees of loan was calculated for each individual. Then the average transaction cost per 100 rupees of loan in each lending source was calculated. It revealed that the Samurdhi Bank borrowers had to incur Rs. 3.81 and the Ceylinco Grameen borrowers had to incur Rs. 0.42 to obtain a Rs. 100 loan. Analysis also revealed that the transaction cost of the Samurdhi Bank borrowers is significantly greater than the Ceylinco Grameen borrowers.

In both lending sources, the transaction cost decreased with the increase in the amount borrowed (Figure 2). Since the components of the transaction cost do not increase drastically with the increase in the loan size the average transaction cost per Rs. 100 loan decreases with the increase in loan size. 


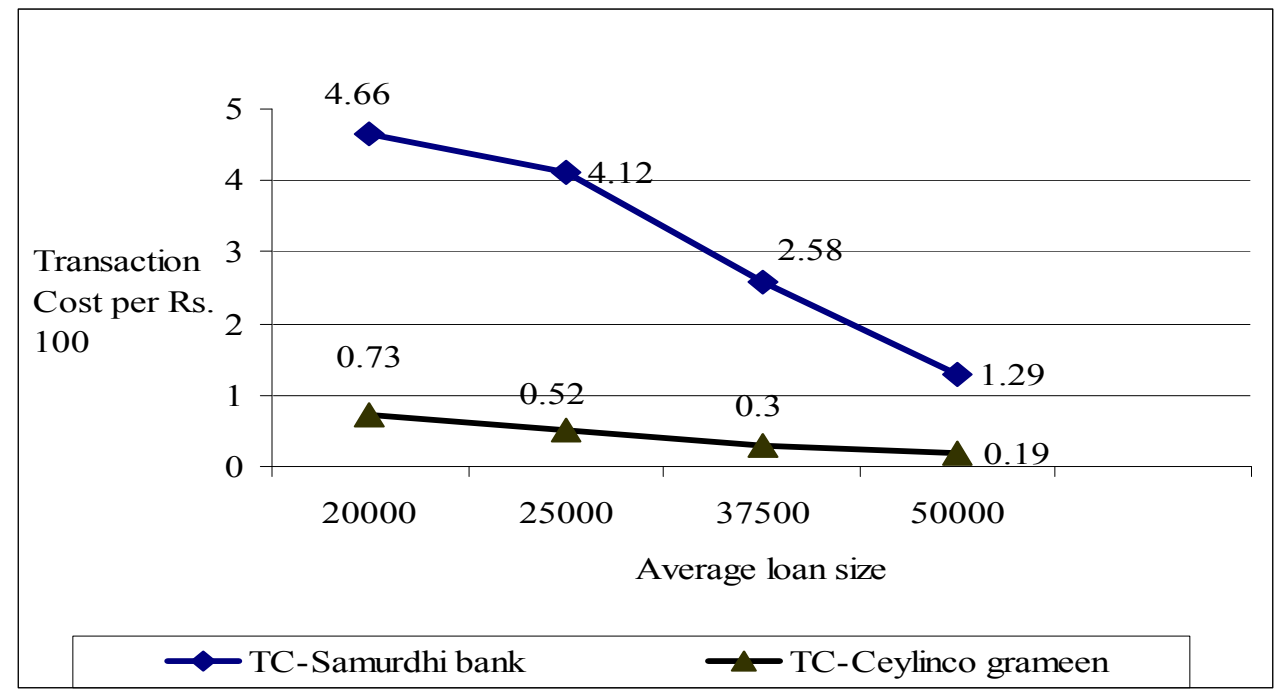

Figure 2: Relationship between the transaction cost and the average loan size

\section{Contribution of each Cost Component to the Transactions Cost}

The borrower's transactions cost in obtaining a Rs. 100 loan was disaggregated to analyze the contribution of each cost component and is presented in Table 2. Accordingly, travel and meal cost gives the highest contribution of $64 \%$ to the Samurdhi Bank borrower's transactions cost. In Ceylinco Grameen, cost of finding guarantors gave the highest contribution of $59 \%$ to the transactions cost.

Table 2: Contribution of each Cost Component to the Total Transactions Cost (\%)

\begin{tabular}{|l|c|c|}
\hline \multicolumn{1}{|c|}{ Cost Component } & $\begin{array}{c}\text { Ceylinco } \\
\text { Grameen } \\
(\boldsymbol{n}=\mathbf{4 5})\end{array}$ & $\begin{array}{c}\text { Samurdhi Bank } \\
(\boldsymbol{n}=\mathbf{4 5})\end{array}$ \\
\hline Travel and meal cost & 14 & 64 \\
Opportunity cost of borrowing & 11 & 35 \\
Cost of finding guarantors & 59 & - \\
Other Costs & 16 & 0.5 \\
\hline
\end{tabular}

In Samurdhi Bank loans, travel and meal cost is high due to the location of the bank. Most of the borrowers have to travel several times to the Samurdhi Bank in order to obtain the loan. Under this scenario, borrowers who lived far away from the bank have to incur a higher traveling cost. The travel and meal cost incurred by the Ceylinco Grameen borrowers was only $14 \%$ and this is primarily due to the completion of pre-loan procedures such as loan application and approval at the village meetings. They have to visit the Branch Office only once to obtain the loan. Therefore, the Ceylinco Grameen borrowers have incurred less on traveling.

The guarantors cost is the highest cost contribution to the transactions cost of Ceylinco Grameen loans and it was 59\%. The other group members have to visit the branch office with the borrower, because they are signing as the guarantors 
for the loan. During this visit the borrower has to pay the travel cost on behalf of the group members. If they live far away from the Nuwara Eliya branch office, the borrower's cost of finding guarantors will increase. Therefore, the cost of finding guarantors is high with the Ceylinco Grameen Loans. But for the Samurdhi Bank loans, group members do not need to travel to the bank in order to sign as guarantors. The borrower can ask the group members to sign the loan application at the village meeting or at any convenient time. Therefore, there is no cost of finding guarantors with respect to Samurdhi Bank loans.

The opportunity cost of borrowing is high in the Samurdhi Bank $(35 \%)$ than in the Ceylinco Grameen loans. This is because the Samurdhi Bank borrowers have to make several visits to the bank in order to obtain the loan. On average, a Samurdhi Bank borrower visits the bank 10 times to complete the pre-loan procedures. The situation is not the same with the Ceylinco Grameen Credit Company Limited, because the Grameen officers come to the village for weekly meetings. Therefore, the opportunity cost of borrowing is low (11\%) with the Ceylinco Grameen loans.

The Ceylinco Grameen borrowers have to sign on a Rs. 10 stamp when obtaining the loan. Therefore, $16 \%$ of the transaction cost of obtaining a Rs. 100 loan is incurred as other costs. The refreshments given to the group members of the Ceylinco Grameen borrowers are also included in the other cost component. There is no such requirement with the Samurdhi Bank.

\section{Gross Unit Cost of Credit}

The Ceylinco Grameen Credit Company Limited provides loans at an interest rate of $26 \%$ per year. But the Samurdhi Development bank provides loans at $18 \%$ per year and the loans under the Janapubudu Programme bear an interest rate of $14 \%$. The gross unit cost is calculated based on the equation described in the methodology: unit transaction cost and interest rate together gives the "gross unit cost". From economic point of view, the "gross unit cost" which is the cost per unit of money borrowed is the most important.

As shown in Table 3, the "gross unit cost" is high with the Ceylinco Grameen loans (Rs. 0.2642) than the Samurdhi Bank loans (Rs. 0.218). Although the unit transaction cost of the Grameen loans is low, the gross unit cost has increased due to high interest cost. But in the Samurdhi Bank loans, the unit transaction cost is higher than the Ceylinco Grameen loans, and interest cost is lower than the Grameen loans. Accordingly, the interest rate is the most important factor that increases the total cost of borrowing from the Ceylinco Grameen. In both sources, the interest cost is higher than the unit transaction cost of borrowing.

Table 3: The gross unit cost of obtaining loans

\begin{tabular}{|l|c|c|}
\hline \multicolumn{1}{|c|}{ Cost Component } & $\begin{array}{c}\text { Ceylinco Grameen } \\
(\boldsymbol{n}=45)\end{array}$ & $\begin{array}{c}\text { Samurdhi Bank } \\
(\boldsymbol{n}=\mathbf{4 5})\end{array}$ \\
\hline $\begin{array}{l}\text { Unit Transaction Cost } \\
\text { (Rs.) }\end{array}$ & 0.0042 & 0.0380 \\
\hline Interest Cost (Rs.) & 0.26 & 0.18 \\
\hline Gross unit cost (Rs.) & 0.2642 & 0.2180 \\
\hline
\end{tabular}




\section{The Borrower's Perception towards the Lending Source}

As described in the methodology, the borrower's perception towards their lending source was estimated based on 14 statements. Analysis of their perception towards the lending sources indicated significant differences across the two lending sources. Ninety five percent of the Samurdhi bank borrowers have a negative perception towards the lending source and it was due to several factors related to the lending source. High transaction cost of borrowing, requirement to visit the bank several rimes in order to get approval for the loan and the untimely approval of the loan were the key factors that lead to have a negative perception. Further, respondents indicated that the Samurdhi bank decides the size of the loan for each individual and the approved loan amount does not meet the needs of the borrower. Also the borrowers indicated that they do not receive any additional services along with the loan even though they request for services like training and marketing support. All these factors have created a high negative perception towards the Samurdhi bank. Only 5\% of the Samurdhi Bank borrowers have a positive perception towards the Samurdhi bank and it was primarily due to the non-requirement of collateral and the possibility of flexible repayment terms. Most importantly, majority of the Samurdhi bank borrowers indicated that the loan has helped to improve their business ventures.

Fifty one percent of the Ceylinco Grameen borrowers have a negative perception towards the lending source. It is mainly due to the repayment plan of the bank which specifies that the loan needs to be paid within 52 weekly installments. When the size of loan increases, weekly installment also increases and hence it creates problems in repayment. However, $49 \%$ of the Ceylinco Grameen borrowers have positive perceptions towards the lending source and is primarily due to easy access, timeliness in loan disbursement, simple procedures, non requirement of the collateral, low transaction cost and proper assistance by the Grameen staff. Majority of the respondents indicated that high interest rate is not a problem for them since it provides loans in a convenient way.

\section{Conclusion}

Findings show that the transaction cost of borrowing reduces with the increase in loan size. The situation is the same with the Ceylinco Grameen Credit Company Limited and Samurdhi bank. Analysis has revealed that the Ceylinco Grameen Credit Company Limited has successfully reduced the borrower's transactions cost unlike the Samurdhi bank because they have tried to apply the fundamentals of the Grameen Bank in Bangladesh which was launched by Yunus in 1983. Similar to the Grameen Bank concept, Ceylinco Grameen has also demonstrated a low transactions cost due to special features of the loan procedure. Closer proximity to the borrower, regular inspection of the microenterprises by the lending staff has created a strong relationship between the borrower and Grameen staff. Timeliness in loan approval and disbursement has built trust on lending. Both the borrowers and lenders of the Ceylinco Grameen Credit Company Limited have realized their responsibilities. Therefore, Ceylinco Grameen could be considered as a successful experiment in microcredit in Sri Lanka. In comparison, the Samurdhi bank lends to their borrowers in a traditional way and it leads to a high transaction cost of borrowing. As it is an important micro-credit institution for the poor microenterprise owners, by incorporating the good points of Ceylinco Grameen lending they can develop their CDS in a successful manner. The Samurdhi Animators or the Bank officers 
could be appointed to inspect the borrowers. It will lead to establish a strong relationship between the borrower and the Bank.

Although the Ceylinco Grameen Credit Company Limited has successfully reduced the transaction cost of borrowing compared to the Samurdhi bank, it has failed to reduce the gross unit cost of borrowing due to the high interest rate. Reducing the transaction cost of borrowing in the Samurdhi Bank loans will reduce the gross unit cost of borrowing. In such a situation, the Samurdhi bank will be a successful lender with a low transaction cost and a low interest rate.

\section{References}

Bhatt, E. 1998. An Overview of the Status of Micro-credit. A Summary Report on Micro-credit Management System (MCMS). Regional Symposium. Ahmedabad. India

Chandradasa, A.J.M. (2004). What is Microfinance?, Economic Review, Vol.30 (9 \& 10), 27-28.

Central Bank of Sri Lanka. (2004). Annual Report. Central Bank of Sri Lanka: Colombo

Delpachitra, S. (2000). Sustainability of Commercial Banks in Microfinance Industry: Some Empirical Evidence. Journal of Co-operative Development, Vol. 3 (1), 24-45.

Department of Census and Statistics (2002). News Bulletin. Department of Census and Statistics. Sri Lanka.

Department of Industrial Development and Promotion (2006). News Bulletin on Small Medium and Micronterprises in Sri Lanka. Department of Industrial Development and Promotion. Sri Lanka.

Egaitsu, F. (1988). Measures to Reduce Transaction Costs in Farm Finance, Improved Agricultural Credit for Small Farmers in Asia and Korea, National Agricultural Cooperative Federation: 1-7.

Kelegama, S., and Thiruchelvam, N. (2001). Structural Adjustment and Employment Creation in Sri Lanka. Institute of Policy Studies, Colombo: 30-37.

Ladman, J.R. (1988). Loan Transactions Costs: Credit Rationing, and Market Structure: The Case of Bolivia. in: Adams, D.W. et al. (ed.) Undermining Rural Development with Cheap Credit. West-view Special Studies in Social, Political and Economic Development.

Miles and Hberman (1994). Transaction Cost: Handbook on Readings on "Agriculture Finance and Rural Financial Market". In: Sanderatne, N. (ed.) Board of Study in Agriculture Economics. Postgraduate Institute of Agriculture. University of Peradeniya.

Morapitiya, R. (1998). The challenges for the Co-operative Movement in the Emerging Market Economy of Sri Lanka: Some aspects from the Rural Financial Sector. Journal of Co-operative Development. Vol.1 (2), 162-168. 
Newman (1979). Transaction Cost: Handbook on Readings on "Agriculture Finance and Rural Financial Market". In: Sanderatne, N. (ed.) Board of Study in Agriculture Economics. Postgraduate Institute of Agriculture. University of Peradeniya.

Orlando, J.S. (1994). Transaction Cost: Handbook on Readings on "Agriculture Finance and Rural Financial Market". In: Sanderatne, N. (ed.) Board of Study in Agriculture Economics. Postgraduate Institute of Agriculture. University of Peradeniya.

Otero and Rhyne (1994). Transaction Cost: Handbook on Readings on "Agriculture Finance and Rural Financial Market". In: Sanderatne, N. (ed.) Board of Study in Agriculture Economics. Postgraduate Institute of Agriculture. University of Peradeniya.

Premaratne, S.P. (2002). Access to Capital: A Comparison of Men and Women Owned Small Businesses in Sri Lanka. Sri Lanka Economic Journal. Vol. 3 (2), 32-51.

Sanderatne, N. (2002). Lending Issues in Rural Finance. Postgraduate Institute of Agriculture. University of Peradeniya. Peradeniya.

Seneviratne, U. (1999). Promoting Microenterprise Sector through Co-operatives. Journal of Co-operative Development.Vol.2 (2), 25-32.

Smith (1999). Quoted in Premaratne, S.P. (2002). Access to Capital: A Comparison of Men and Women Owned Small Businesses in Sri Lanka. Sri Lanka Economic Journal.

Yunus, M. (1999). A Small Experiment Begun in Bangladesh has turned into a Major New Concept in Eradicating Poverty. The Grameen Bank. Journal of Scientific American. 90-93.

Yunus, M. (2000). www.grameeenfoundation.org. 